\title{
Guest Editorial
}

One of the most important theological (re-)discoveries of the twentiethcentury ecumenical and missional movements is missio Dei ("the mission of God" or "the missionary God"); grounding or realigning the mission of the church in the character of God as a missionary God. It was a clarion call of numerous gatherings since Willingen 1952, but its implications and practice are still being outworked and need further development for local mission contexts. The concept of missio Dei has also been the subject of disagreement and debate, and with renewed interest in the concept nearly seventy years on, new opportunities for resolving those debates, or moving beyond the concept, are emerging.

This special edition of Mission Studies invited contributions that explore the history, theology, development and implications of Missio Dei, and especially how it is understood and expressed in different contexts of Oceania. International Association for Mission Studies (IAMS) is hosting its Fifteenth Assembly in Sydney, Australia on 9-15th July 2020 on the theme "Powers, inequalities and vulnerabilities: Mission in a wounded world". ${ }^{1}$ This March 2020 edition of the journal showcases mission studies in our region of Oceania, underlining how we can learn about aspects of missio Dei from other cultures, women and not just men, disciplinary research, denominations and local churches.

Hone Te Riri and Steve Taylor weave creation and redemption themes in light of indigenous Oceanic (Māori) epistemologies and understandings of water, including ocean voyaging, ancestor understandings of whirlpools, Māori water rites and oral history of river beings (taniwha), all in conversation with Gospel narratives of baptism. Read this unique expression of Māori theology and consider how missio Dei is an immersion in God, and how we have much to learn from the gifts of indigenous knowing. Moreover, in the context of global warming and our urgent need for Creation Care, it is important to foster attentiveness to the world's oceans and water sources, and these writers from the Pacific Ocean model fresh discernment.

The theme of learning about missio Dei from others continues in subsequent articles. Rosemary Dewerse and Cathy Hine challenge us to give priority and attention to seeking and listening to the voices of the Global South and of women. As Oceanic women, from Aotearoa New Zealand and Australia

1 Note from the editor at the time of going to press: This conference was postponed due to COVID-19. 
respectively, they interrupt the missional hermeneutics discourse and invite us to read Scripture and particularly the Beatitudes in light of the missio Dei and from their twice-under perspective. Read this exceptional article and consider how the stories of those on the margins, including a number of inspiring women whose ministry was shaped by the missio Dei, have brought comfort and justice, mercy and peace in troubled Oceanic and biblical contexts.

Lynne Taylor offers insight into how missiological research can help us discern where and how God is working in the world. She proposes critical realism and grounded theory as ways for exploring the missio Dei, and shows how she used those in her fascinating research of how secular (unchurched) Australians are becoming Christians. Read this and consider how well designed research with sound methodology can help avoid "bracketing" God out and instead discern the missio Dei.

David Williams turns his attention denominationally to how Sydney Anglican theology, with its priority on mission as proclamation and evangelism, locates care for the poor. Interviews with Moore Theological College faculty show how care for the poor is located in the life of the disciple of Jesus Christ and in the community life of the local church. Read this and consider whether the Sydney Anglican alternative voice that Williams identifies of how the missio Dei is expressed, and how social concern can be freshly integrated in local church ministry, has biblical and missiological validity.

George Wieland helpfully delves into a local church case study of Māngere Baptist Church in South Auckland, Aotearoa New Zealand. He carefully seeks to discern and discuss how missio Dei is expressed in its community engagement including learning from Māori people and advocating for local justice issues. Read this inspiring snapshot of congregational revitalization and consider their example of moving on from asking "How can I grow my church?" to "How can we transform the community?" or even better asking, "How can we follow God as he transforms this community?"

The final article is where I, Darren Cronshaw, explore more generally the implications of missio Dei for local churches, and expand on that to investigate the deeper implications of missio Trinitas ("the mission of the Trinity") for churches. Drawing on my reading of some of the missional church literature, I argue it is essential (and liberating) to focus on the fullness of what it means to share the whole life of God with the whole world through the whole people of God. There are significant implications for the agency of God, spirituality of mission, holistic mission and the call on all Christians as missionaries especially as communities not just individuals.

Oceania in centered around the tropical Pacific Ocean and spans over 8.5 million square kilometers. With a combined population of 38 million in 2018 , it has $0.54 \%$ of the world's population. It includes 14 countries and 
other territories across four regions of Melanesia Micronesia, Polynesia and Australasia. In 2018, we also have 18 of an international total of 161 IAMS individual members, and 1 of 13 honorary members. So while there are only $0.54 \%$ of world population in Oceania, $11 \%$ of IAMs members are from this region!

The diversity of Oceanian missiology is not fully represented in this edition, but we do have three contributors from Australia and five from Aotearoa New Zealand.

One aspect of diversity throughout Oceania is of course our linguistics. Across the large families of Austronesian, Aboriginal Australian and Papuan languages there are (or were) over 2000 languages. Through the region there are also speakers of four colonial languages, various Creoles and dozens of immigrant languages.

Hone Te Riri and Steve Taylor helped me understand that in their country, Aotearoa New Zealand, Māori is an official language, along with English and New Zealand Sign Language (NZSL). Thus, they never italicise Māori words. If words are italicised, it is considered colonial - a way of asserting the superiority of English in a land committed to partnership and respect through the Treaty of Waitangi.

This journal Mission Studies is written in English. Nevertheless, this is a special edition from Oceania and thus committed to respecting indigenous cultures. Hone Te Riri and Steve Taylor model this for us with their collaborative article. As a postcolonial move and mark of respect for indigenous languages, they do not treat Māori or any language other than English as exotic, as other, as different, as needing to be italicised, but as mainstream and of equal status. As contributors of all articles and in the editorial process we follow this practice out of respect for all languages, whether ancient indigenous languages such as Māori, or ancient Western languages such as Latin. Thus perceptive readers will notice, for example, that missio Dei is not italicized.

Missio Dei reminds us that mission is what God is doing in the world, with which God invites the church to cooperate. This is helpfully becoming a mainstream theological framework. It has certainly broadened missiological and theological horizons around the world. This edition of Mission Studies illustrates how some of us in Oceania, or more specifically Australasia, are unpacking its implications for our context. It is significant that the writers call attention to the local, to women and to indigenous voices, and to discerning where God is active in grassroots ministry. We hope the contributions gives you insights into what God is doing in our 'down under' corner of the world.

\section{Darren Cronshaw}

Australian College of Ministries, Sydney College of Divinity, Sydney, Australia dcronshaw@acom.edu.au 